\title{
The Effectiveness of Mobile Blended Problem Based Learning on Mathematical Problem Solving
}

\author{
https://doi.org/10.3991/ijim.v15i01.17437
}

\author{
Ahmad Kholiqul Amin ( $\left.{ }^{\bowtie}\right)$ I Nyoman Sudana Degeng, \\ Punaji Setyosari, Ery Tri Djatmika \\ Universitas Negeri Malang, Malang, Indonesia \\ choliqaminegmail.com
}

\begin{abstract}
This study aimed to examine the effectiveness of mobile blended compared to conventional problem-based learning on mathematical problemsolving skills and look for students' responses about the use of online learning. The study was conducted using a pretest-posttest quasi-experimental research design supported with descriptive qualitative responses involving 188 students taken by applying cluster random sampling as subjects of research distributed from vocational high schools in Bojonegoro City, East Java, Indonesia. Research findings revealed that mathematical problem-solving skills for students treated with mobile blended problem-based learning were higher than those who have been treated with purely problem-based learning. In addition, students have responded positively to the usage of mobile blended problem-based learning that was applicable and acceptable for effectively improving mathematical problemsolving skills.
\end{abstract}

Keywords - Mobile learning, blended learning, problem-based learning, problem-solving

\section{$1 \quad$ Introduction}

In this $21^{\text {st }}$ Century, students are required to have various skills such as critical thinking and problem solving [1] that are essential for them [2]. Problem-solving skills reinforce critical thinking ability [3]. Furthermore, students are expected to develop themselves through ICT, information, media, and computing literacies [4]. The development of information technology provides students with challenges and opportunities to develop themselves through online learning [5]. This is relevant to the current education situation in Indonesia that the learning process is delivered through information technology and rapid development of information technology is beneficial to support learning activities.

To stimulate students' problem-solving skills, an appropriate learning model is needed. One of the learning models which can improve students' problem-solving skills is problem-based learning (PBL) [6]. PBL can stimulate students to think systematically since it is a student-centered learning model (SCL) [7] so that it provides experience to students to carry out activities directly in solving problems. PBL provides training to 
students in applying various principles, concepts, and skills that have been learned to solve the problems faced [8].

Many studies recommend PBL to be implemented to teaching various subjects, including Mathematics. Mathematics is a compulsory subject at every level of education, from elementary to university level, but some students find it challenging to learn because it is an abstract subject. Several studies reveal that students get difficulties in learning mathematics. They tend to memorize formulas but do not understand the origin of those formulas, and they have a lack of accuracy in identifying questions in the form of narration [9]. Based on mathematics subjects' characteristics, students must have logical, systematic, and structural thinking ability and high imagination. Therefore, if PBL is applied to mathematics learning, it is expected to improve students' mathematics competence.

However, PBL also has some weaknesses, such as it needs more time allotment for its implementation [10], [11]. Another study uncovered that PBL requires a lot of time allocation from the teacher's perspective compared to traditional learning [12]. It does not provide a significant effect if it is applied in a short time.

Several studies are investigating the effects of blended learning during PBL implementation. The studies revealed that integrating PBL with online learning can increase students' motivation and improve students' literacy skills [13]. The application of PBL is more efficient if it is integrated with online learning [14]. A meta-analysis study also shows that blended-PBL is more effective compared to conventional PBL [15]. Blended-PBL is effective in increasing the students' activeness in learning activities [16]. Another study also revealed that integrating mobile devices and PBL can improve students' critical thinking skills [17].

Several studies have investigated blended PBL focusing on specific materials, subjects, fields, and frequently conducted at the university level, such as in accounting [18], health [14], and a very limited study conducted at secondary schools. In addition, the study mostly included a limited number of subjects, the scope of skills analyzed [13], and mastery of knowledge comprehensiveness [15]. Based on several studies related to blended PBL and rapid development of mobile technology in all sectors including education, mobile devices have become people's daily needs since it offers a new paradigm of connectivity, communication, and collaboration [19]. Therefore, researchers intended to integrate some ideas from blended learning, problem- based learning, and mobile learning, where learning is an integration of blended PBL and mobile devices. Students were facilitated in accessing learning information provided by teachers through the Schoology platform as a learning management system (LMS). All related learning materials and problems were arranged in the LMS, by providing journal articles links and YouTube video links. Accordingly, students can study easily anywhere, at any time, and access content many times as long as the internet connection is available. The integration of mobile learning, blended learning, and PBL, also known as MBPBL, makes it possible to change the teaching and learning process[20]. This is because learning with mobile devices' help is not only learning in a formal environment (school) but also learning outside of school all the time using mobile devices[21]. Another study also states that mobile devices also negatively impact if they are misused so that student performance decreases, such as when learning occurs, students do other activities such as watching movies, playing games, chatting on social media, and so on[22]. This is due to student pedagogical factors. To overcome this, it is necessary to 
explain at the first meeting regarding students' intention and behavior in using mobile devices.

From the explanation above, it can be stated that this study is focused on revealing that: 1) whether or not the implementation of MBPBL is more effective than conventional PBL, and 2) the students' responses about the implementation of MBPBL in mathematics learning.

\section{$2 \quad$ Literature Review}

\subsection{Mobile Learning (ML)}

Teachers need to be able to take advantage of mobile learning technologies to support education 4.0. Mobile learning is a form/learning model using the capabilities of mobile devices [23] Since 2005, the word "mobile learning" has been introduced [24] by many researchers. However, with the development of mobile devices, it currently has numerous e-learning capabilities. It is unique in that it is flexible, in terms of time and place, to transform learning into different contexts, such as multimedia and communication contents [25]. Mobile learning is not only about learning materials, it also encourages students to learn more about learning [25]. Mobile education can also be involved in learning in Indonesia. However, it is rare to combine mobile learning with some approaches [26], such as mobile learning with mixed learning and problembased learning. Most research results are limited to examining the efficiency of mobile learning and samples in higher education institutions without using a specific learning approach model.

The types of methods that can be facilitated by mobile devices include a) individual learning, where students can learn at their own pace; b) distance learning, namely situational learning; c) interactive learning, which is easy to connect and communicate. Based on this study, the efficacy of mobile learning combined with certain approaches is examined.

\subsection{Blended Learning(BL)}

Blended learning is a form of learning that incorporates face-to-face and online models using all technological facilities, or in other words, it is a blend of face-to-face and online learning [27]. According to [28] blended learning model typically includes six mixed learning models, namely: 1) face-to-face Driver Model, 2) Rotation Model, 3) Flex Model, 4) Online Lap Model, 5) Self-Blend Model, 6) Online Driver Model. The keys to blended learning, according to [29], are: 1) Live Event, 2) Self-paced Learning, 3) Collaboration, 4) Assessment, 5) Performance Support Materials.

Referring to the six blended learning models, this study used the online driver model. This study used the Schoology platform for online activities. Further, there is no standard formula for determining the mixture of online and offline meetings in the context of learning [30]. The standard percentage use is 50/50, which means that faceto-face learning is done by $50 \%$, and online learning is also done by $50 \%$. In addition to the above composition, some apply $75 \%$ of face-to-face learning and $25 \%$ of online 
learning or vice versa. In this study, the researchers used $50 \%$ of face-to-face learning and $50 \%$ of online learning.

\subsection{Problem Based Learning (PBL)}

The learning step of problem-based learning consists of five stages, which are initiated with problem-posing and ended with students' works presentation and problem-solving analysis. The five stages which were adapted from [31] are presented as follows.

Table 1. The Steps of Problem Based Learning

\begin{tabular}{|c|l|l|}
\hline No & \multicolumn{1}{|c|}{ Stages } & \multicolumn{1}{|c|}{ Teacher's Activity } \\
\hline 1 & Problem posing & Distributing worksheets containing the problem posed \\
\hline 2 & Learning organization & $\begin{array}{l}\text { Setting the problem or discussing the problem with } \\
\text { students } \\
\text { Guiding the students to analyze the problem }\end{array}$ \\
\hline 3 & Guiding an individual or group investigation & $\begin{array}{l}\text { Guiding the students in group to analyze the problem } \\
\text { (brainstorming session) } \\
\text { Guiding the students in group to formulate the learning } \\
\text { objectives }\end{array}$ \\
\hline 5 & $\begin{array}{l}\text { Developing and presenting the students' } \\
\text { works }\end{array}$ & $\begin{array}{l}\text { Guiding the students to examine the result of group } \\
\text { discussion in a class discussion forum } \\
\text { The group of students presents the results of the } \\
\text { discussion through a class presentation }\end{array}$ \\
\hline Analyzing and evaluating the problem- & $\begin{array}{l}\text { Explaining unfamiliar terminology and concept related } \\
\text { to learning material } \\
\text { Guiding the students to conclude the lesson }\end{array}$ \\
\hline
\end{tabular}

Source: [31]

\subsection{Mobile Blended Problem-Based Learning (MBPBL)}

Researchers combined mobile learning (ML), blended learning (BL), and problembased learning (PBL), known as mobile blended problem-based learning (MBPBL), as a learning strategy. MBPBL was implemented using the syntax of PBL that included a face-to-face meeting in class combined with online PBL utilizing a mobile device with the Schoology platform that was previously designed and developed. The students attended the face-to-face class and communicated and collaborated electronically outside the classroom using the LMS Schoology platform that has been provided. PBL learning step follows the theory of constructivism and is centered on students' activities [32]. This integration is necessary since blended learning must be integrated with constructive learning [33]. Therefore, the theory is used as a basis for a theoretical blend of blended learning and PBL. Many evidences have revealed that blended learning and constructive learning support each other in creating a harmonious learning environment. 
Table 2. The Steps of MBPBL

\begin{tabular}{|c|c|}
\hline Stages & Learning through LMS Platform \\
\hline $\begin{array}{l}\text { Learning } \\
\text { Preparation }\end{array}$ & $\begin{array}{l}\text { The teacher provides an online learning environment through the LMS Platform } \\
\text { with the following criteria: } \\
\text { a) Online learning is a medium of learning the activities are carried out } \\
\text { outside the face-to-face learning in class. } \\
\text { b) Online learning is equipped with discussion materials, learning } \\
\text { materials, quizzes, assignments, pictures, videos, or website addresses. } \\
\text { c) The teacher states the learning goals and problems as a stimulus for } \\
\text { students through a video. } \\
\text { d) It uses the problem as a learning stimulus delivered via online. } \\
\text { e) Each student tries to find a solution to the problem posed, to be } \\
\text { fiscussed in their respective groups. } \\
\text { g) The teacher guides analyzing problems. } \\
\text { h) The teacher guides information gathering and online discussion forum. } \\
\text { i) The teacher guides students to test the results of group discussions in } \\
\text { online discussion forums. } \\
\text { j) The teacher explains unfamiliar terminology and concepts related to } \\
\text { k) The teacher gives assignments and information related to classroom } \\
\text { learning that will be held next. } \\
\text { Learning activities are carried out flexibly, depending on the }\end{array}$ \\
\hline Pre-Activity & $\begin{array}{l}\text { a) The teacher checks the readiness of the class, learning tools, and } \\
\text { learning media. } \\
\text { b) The teacher greets the students. } \\
\text { c) The teacher checks students' attendance. }\end{array}$ \\
\hline Opening & $\begin{array}{l}\text { a) The teacher makes apperception, gives motivation, and explains the } \\
\text { steps of learning. } \\
\text { b) The teacher divides students into some groups consisting of } 4-5 \\
\text { students. }\end{array}$ \\
\hline Main Activity & $\begin{array}{l}\text { a) The teacher distributes Students' Worksheets, which contains the } \\
\text { problem posed to support the learning process. } \\
\text { b) The teacher sets the problem or discusses the problem together with } \\
\text { the students. } \\
\text { c) The teacher guides students to analyze the problem. } \\
\text { d) The teacher guides students to describe systematic explanations from } \\
\text { problem analysis in groups (brainstorming sessions). } \\
\text { e) The teacher guides students to formulate learning goals in groups. } \\
\text { f) The teacher guides students to search for information independently in } \\
\text { groups via the internet. } \\
\text { g) The teacher guides students to gather information in a group } \\
\text { h) The teacher guides students to test the results of group discussions in } \\
\text { i) The teacher explains unfamiliar terminology and concepts related to } \\
\text { The forum. }\end{array}$ \\
\hline Closing & $\begin{array}{l}\text { The teacher guides students to conclude the lesson. } \\
\text { The teacher provides assignments and information related to online } \\
\text { learning that will be held next. }\end{array}$ \\
\hline
\end{tabular}

Adapted from [34]-[37]

This MBPBL has some benefits. First, it provides students with a more flexible and constructivist learning environment with the Schoology mobile platform device's help. 
They can control their learning and learn with a variety of dynamic learning resources. In an integrated learning environment, students and teachers are freed from time and space limitations from traditional classrooms. Second, MBPBL learning promotes interaction and collaboration between students and teachers by enabling them to communicate and collaborate both in online and in the classroom. MBPBL learning has the potential to provide passive students in a face-to-face environment with the opportunity to participate in collaborative problem-solving actively. The studies [38][42] show that passive students tend to participate more actively in online media than face-to-face learning. The following table presents the advantages of MBPBL compared to PBL.

Table 3. The Advantages of MBPBL Compared to PBL

\begin{tabular}{|c|c|c|}
\hline Indicators & MBPBL & PBL \\
\hline Time allocation for learning & $\begin{array}{l}\text { The time for learning is longer since } \\
\text { it is not limited to learning hours } \\
\text { like in a class so that the students } \\
\text { have more time to understand the } \\
\text { material. }\end{array}$ & $\begin{array}{l}\text { The time for learning is limited to } \\
\text { learning hours in a class. }\end{array}$ \\
\hline Learning ease & $\begin{array}{l}\text { With mobile devices' aid, the } \\
\text { students can learn every time and } \\
\text { everywhere and can access the } \\
\text { material many times. The learning } \\
\text { sources are also rich since they are } \\
\text { taken from books and online } \\
\text { sources, e.g., YouTube, Weblogs, } \\
\text { etc. }\end{array}$ & $\begin{array}{l}\text { The learning activity must take } \\
\text { place in class, and the learning } \\
\text { source is limited to printed books. }\end{array}$ \\
\hline Discussion & $\begin{array}{l}\text { The students can have a discussion } \\
\text { or communication with their teacher } \\
\text { and peers without a face-to-face } \\
\text { mode. They can do it online. }\end{array}$ & $\begin{array}{l}\text { The discussion can only be done } \\
\text { through face-to-face meetings in } \\
\text { class. }\end{array}$ \\
\hline Learning control / management & $\begin{array}{l}\text { Through the mobile device, the } \\
\text { learning activities done outside the } \\
\text { class can be well-managed by the } \\
\text { teacher. }\end{array}$ & $\begin{array}{l}\text { There is no control for learning } \\
\text { activities outside the class. }\end{array}$ \\
\hline Evaluation & $\begin{array}{l}\text { Through the mobile device, the } \\
\text { teacher can make an online quiz, } \\
\text { give the students feedback, and } \\
\text { utilize the test results well through a } \\
\text { learning management system } \\
\text { (LMS). }\end{array}$ & $\begin{array}{l}\text { Evaluation can only be done in } \\
\text { class. }\end{array}$ \\
\hline Sharing & $\begin{array}{l}\text { The students can easily share } \\
\text { information, material, and files } \\
\text { through LMS with one another. }\end{array}$ & $\begin{array}{l}\text { There is no certain way of sharing } \\
\text { files, material, or information. }\end{array}$ \\
\hline
\end{tabular}

\section{$3 \quad$ Research Method}

\subsection{Research design}

This research was conducted using a quasi-experimental pretest-posttest design and supported with descriptive qualitative statements from students concerning the 
implementation of mobile blended learning. A pre-test was administered to both groups before the treatment was given to measure students' mathematical problem-solving skills. This pre-test was necessary to confirm that the two groups were indifferent. After the pre-test was done, the researchers gave treatment to the sample in 8 meetings, and it was ended with a post-test. This post-test was intended to measure the students' achievement after the treatment. Besides, the researchers also distributed questionnaires to the students and interviewed with them. The detailed information about the research design is presented as follows.

Table 4. Research design

\begin{tabular}{|c|c|c|c|c|c|c|c|c|c|c|}
\hline & \multicolumn{10}{|c|}{ Meeting } \\
\hline & & 1 & 2 & 3 & 4 & 5 & 6 & 7 & 8 & \\
\hline \multirow{2}{*}{ Class } & Pre-test & \multicolumn{8}{|c|}{ Experimental Class } & Post-test \\
\hline & Pre-test & \multicolumn{8}{|c|}{ Control Class } & Post-test \\
\hline
\end{tabular}

The treatments for experimental and control groups were given for eight weeks both for mobile blended and conventional problem-based learning. The mode of learning for the experimental group consisted of four times face-to-face and four times online, while the mode of learning for the control group was eight times fully face-to-face. The detail of learning mode arrangements for the experimental and control group is shown in Tables 5 and 6 below.

Table 5. Mode of Learning Arrangements for Experimental Group

\begin{tabular}{|l|l|l|}
\hline \multicolumn{1}{|c|}{ Weeks } & \multicolumn{1}{|c|}{ Mode of learning } & \multicolumn{1}{c|}{ Learning Materials } \\
\hline 1st Week & Face-to-face & $\begin{array}{l}\text { Introduction, explanation of the learning model that will be } \\
\text { applied, tutorial learning with the LMS platform (online), } \\
\text { learning contract }\end{array}$ \\
\hline 2nd Week & Online & Arithmetic Sequences \\
\hline 3rd Week & Face-to-face & Arithmetic Progression \\
\hline 4th Week & Online & The Application of Arithmetic Sequences and Progression \\
\hline 5th Week & Online & Geometric Sequences \\
\hline 6th Week & Face-to-face & Geometric Progression \\
\hline 7th Week & Online & Infinite Geometric Progression \\
\hline 8th Week & Face-to-face & The Application of Geometric Sequences and Progression \\
\hline
\end{tabular}

Table 6. Mode of Learning Arrangements for Control Group

\begin{tabular}{|l|l|l|}
\hline \multicolumn{1}{|c|}{ Weeks } & \multicolumn{1}{|c|}{ Mode of learning } & \multicolumn{1}{c|}{ Learning Materials } \\
\hline $1^{\text {st }}$ Week & Face-to-face & $\begin{array}{l}\text { Introduction, explanation of the learning model that will be } \\
\text { applied, learning contract }\end{array}$ \\
\hline $2^{\text {nd }}$ Week & Face-to-face & Arithmetic Sequences \\
\hline $3^{\text {rd }}$ Week & Face-to-face & Arithmetic Progression \\
\hline $4^{\text {th }}$ Week & Face-to-face & The Application of Arithmetic Sequences and Progression \\
\hline $5^{\text {th }}$ Week & Face-to-face & Geometric Sequences \\
\hline $6^{\text {th }}$ Week & Face-to-face & Geometric Progression \\
\hline $7^{\text {th }}$ Week & Face-to-face & Infinite Geometric Progression \\
\hline $8^{\text {th }}$ Week & Face-to-face & The Application of Geometric Sequences and Progression \\
\hline
\end{tabular}


After eight-week treatments, the two groups were given a post-test. The data collection instruments used in this study were classified as quantitative and qualitative.

\subsection{Population and sample}

This study population is a vocational high school in Bojonegoro city, East Java Province, Indonesia. The subjects of the study included 188 students taken by using cluster random sampling. A number of 94 students were randomly assigned as the experimental groups. The same number of students were assigned as control groups. The experimental group was treated using mobile blended problem-based learning, while the control group was treated using conventional problem-based learning.

\subsection{Instrument (Quantitative method)}

The quantitative methods employed in this study were tests and questionnaires. In this study, the test was a test of mathematical problem-solving skills conducted before treatment (pre-test) and after treatment (post-test). The treatment was done in 8 meetings for each of the MBPBL and PBL class. Meanwhile, the questionnaire was used to uncover students' responses to the implementation of MBPBL. The questionnaire used a Likert scale form. Before being distributed to students, the test instrument and questionnaire were validated by experts.

Table 7. The Blueprint of Problem-solving Questions

\begin{tabular}{|l|c|}
\hline \multicolumn{1}{|c|}{ Basic Competences } & Number \\
\hline The $\mathrm{n}^{\text {th }}$ term of an arithmetic sequence & 1,2 \\
\hline The sum of $\mathrm{n}$ terms of an arithmetic series & $3,4,5$ \\
\hline The $\mathrm{nth}$ term of a geometric sequence & 6,7 \\
\hline The sum of the first $\mathrm{n}$ terms of the geometric series & 8 \\
\hline Infinite geometric series & 9,10 \\
\hline
\end{tabular}

Table 8. The Blueprint of Students' Questionnaire

\begin{tabular}{|c|l|c|c|}
\hline No. & \multicolumn{1}{|c|}{ Statements } & Agree & Disagree \\
\hline 1 & Responses to the applied learning model & & \\
\hline 2 & Alternative learning media & & \\
\hline 3 & Increase the responsibility for the task & & \\
\hline 4 & New experiences with the applied model & & \\
\hline 5 & Save time and money & & \\
\hline 6 & Ease of learning & & \\
\hline 7 & Improve student understanding & & \\
\hline 8 & Ease of collecting assignments & & \\
\hline 9 & Learning models can increase self-confidence & & \\
\hline 10 & Learning models can reduce student anxiety & & \\
\hline
\end{tabular}




\subsection{Instrument (Qualitative method)}

Dealing with the qualitative method, the instruments used were in-depth interview protocol and observation sheet. In this study, the in-depth interview was limited to 3 informants from each MBPBL and PBL class. The MBPBL class observation was done by looking at the students' activeness in online learning using the Schoology platform. Meanwhile, the observation in the PBL class was done by making notes in the observation sheet. The interview guidelines are as follows: 1) Implementation models of learning responses; 2) Implementation of learning models to other subjects; 3) Response to content understanding.

\subsection{Data analysis}

The technique of quantitative data analysis used in this study was the independent samples $t$-test. Then, it proceeds to the N-Gain Score test. The independent samples $t$ test was used to test whether there are differences between the MBPBL class and the PBL class, while the N-Gain Score test was used to see the learning model's effectiveness. Researchers used SPSS version 20 software to process data to look for differences in the learning outcomes of the MBPBL and PBL and their effectiveness. The following is the statistical manual formula for the T-test and the N-Gain test to test the model's efficacy.

The Formula of T-test Independent

$$
t=\frac{\bar{X}_{1}-\bar{X}_{2}}{\sqrt{\frac{\left(n_{1}-1\right) S_{1}^{2}+\left(n_{2}-1\right) S_{2}^{2}}{n_{1}+n_{2}-2}\left(\frac{1}{n_{1}}+\frac{1}{n_{2}}\right)}}
$$

Note:

$\bar{X}_{1}=$ The mean score of sample 1

$\bar{X}_{2}=$ The mean score of sample 2

$n_{1}=$ The number of sample 1

$n_{1}=$ The number of sample 2

$S_{1}^{2}=$ The variance of sample 1

$S_{2}^{2}=$ The variance of sample 2
The Formula of N-Gain Test

$\langle\boldsymbol{g}\rangle=\frac{\left\langle\boldsymbol{S}_{\text {Post }}\right\rangle-\left\langle\boldsymbol{S}_{\text {Pre }}\right\rangle}{\mathbf{1 0 0} \%-\left\langle\boldsymbol{S}_{\text {Pre }}\right\rangle}$

Note:

$\langle g\rangle=$ Gain Score

$S_{\text {Post }}=$ Score of Post test

$S_{\text {Pre }}=$ Score of Pre Test

For qualitative data, the analysis technique used was the triangulation of sources based on interviews and observations. 


\section{Result}

\subsection{Interface system}

Below is a presentation of LMS Schoology in 3 schools performed in MBPBL learning by research subjects. The LMS contains content, individual tasks, group tasks, discussion rooms, and quizzes. The information folder is used to label similar materials like e-books, YouTube links, or papers. Similarly, other activities, such as individual and group tasks, maybe categorized by groups and individuals. For discussion activities and quizzes, the students answered using a special menu.

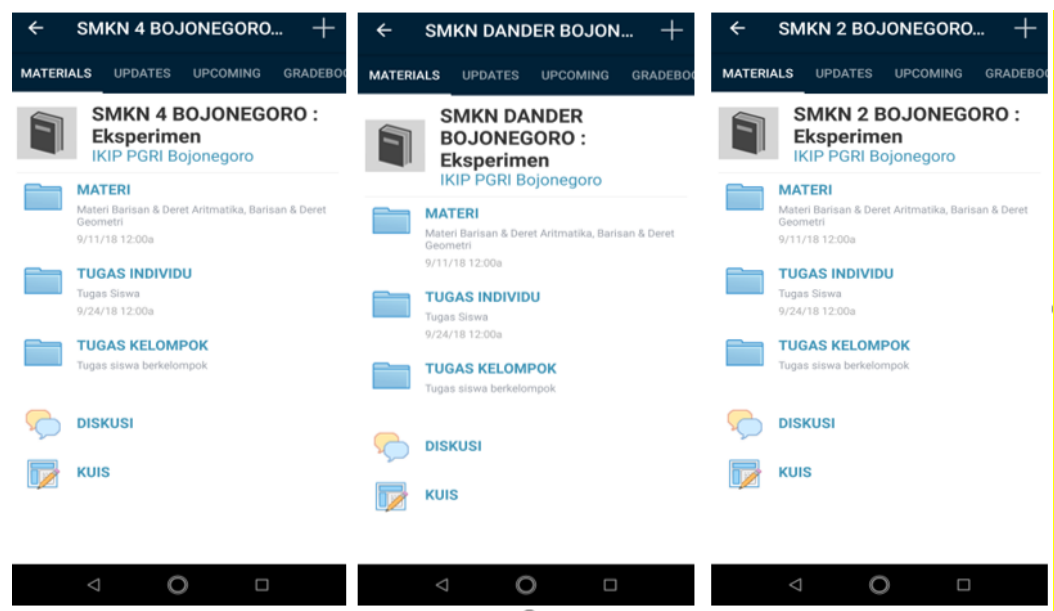

Fig. 1. The Presentation of LMS Schoology

\subsection{The effectiveness of mobile blended and conventional problem-based learning on students' mathematical problem-solving skills}

To analyze the effectiveness of MBPBL compared to PBL on students' mathematical problem-solving skills begins with describing the results of normality tests and homogeneity tests of experimental and control classes, then proceed to describe the students' mathematical problem-solving skills before and after treatment. The pre-test scores were used to determine the students' initial mathematical problem-solving skills in experimental and control classes. In comparison, the post-test scores were used to determine the students' mathematical problem-solving skills after being treated in the experimental and control classes. The followings are the results of normality and homogeneity tests. 
Table 9. The Results of Normality Test of the Students' Mathematical Problem-Solving Skills

\begin{tabular}{|l|l|c|c|c|}
\hline \multirow{2}{*}{ Types of Data } & \multirow{2}{*}{ Groups } & \multicolumn{3}{|c|}{ Kolmogorov-Smirnov $^{\mathbf{a}}$} \\
\cline { 3 - 5 } & & Statistic & $\boldsymbol{d f}$ & Sig. \\
\hline \multirow{2}{*}{ Pre-test } & Experimental & 0.86 & 94 & 0.085 \\
\cline { 2 - 5 } & Control & 0.85 & 94 & 0.090 \\
\hline \multirow{2}{*}{ Post-test } & Experimental & 0.89 & 94 & 0.062 \\
\cline { 2 - 5 } & Control & 0.87 & 94 & 0.075 \\
\hline
\end{tabular}

Table 9 shows the normality test results of pre-test and post-test analysis of both the experimental and control classes. The sig values are $>0.05$, so it can be concluded that the data in this study are in a normal distribution. Whereas for the homogeneity test, both for pre-test and post-test are presented in table 8 below.

Table 10. The Results of Homogeneity Test of the Students' Mathematical Problem-Solving Skills

\begin{tabular}{|l|c|c|}
\hline \multicolumn{1}{|c|}{ Types of Data } & Levene Statistic & Sig. \\
\hline Pre-test & 0.000 & 0.994 \\
\hline Post-test & 0.990 & 0.754 \\
\hline
\end{tabular}

Based on Table 10, the results of the test show that each of the pre-test and post-test sig values are $>0.05$ so that it can be concluded that each group has a homogeneous variant. In conclusion, the requirements for the next analysis are fulfilled. The results of the pre-test and post-test scores are presented as follows.

Table 11. The Pre-and-Post Test Scores of the Students' Mathematical Problem-Solving Skills

\begin{tabular}{|l|c|c|c|c|}
\hline \multirow{2}{*}{\multicolumn{1}{c|}{ Description }} & \multicolumn{2}{|c|}{ Pre-test Scores } & \multicolumn{2}{c|}{ Post-test Scores } \\
\cline { 2 - 5 } & $\begin{array}{c}\text { Experimental Class } \\
(\mathbf{M B P B L})\end{array}$ & Control Class (PBL) & $\begin{array}{c}\text { Experimental } \\
\text { Class. (MBPBL) }\end{array}$ & $\begin{array}{c}\text { Control Class } \\
(\boldsymbol{P B L})\end{array}$ \\
\hline Number of Students & 94 & 94 & 94 & 94 \\
\hline Maximum Score & 90 & 90 & 100 & 95 \\
\hline Minimum Score & 38 & 36 & 52 & 47 \\
\hline Standard Deviation & 14.87 & 15.15 & 14.68 & 14.68 \\
\hline Mean Score & 61.43 & 59.23 & 75.45 & 70.45 \\
\hline
\end{tabular}

The results of the analysis in table 11, the mean score of the students' initial mathematical problem-solving skills/before treatment in the experimental class is 61.43 , and the mean score of the students' initial mathematical problem-solving skills/before treatment in the control class is 59.23. Based on these data, it can be said that the experimental class and the control class have almost similar initial abilities with the difference of 2.20 .

Meanwhile, the mean score of post-tests of the students' mathematical problemsolving skills (after treatment) in the experimental class (MBPBL) is 75.45; and in the control class (PBL) is 70.45 . This shows that both classes have different mathematical 
problem-solving skills, with a difference of 5.0. Then, to determine whether or not there is a significant difference in post-test mean scores in the experimental and control classes, an independent sample t-test was done. The results of the independent sample t-test using the SPSS program are presented in table 10.

Table 12. The Analysis of Post-Test Mean Scores (The Students' Mathematical Problem-Solving Skills after Treatment)

\begin{tabular}{|l|c|c|l|}
\hline Types of Data & Sig. Value & $\boldsymbol{\alpha}$ & \multicolumn{1}{c|}{ Conclusion } \\
\hline Post-test & 0.015 & 0.05 & $\begin{array}{l}\mathrm{H}_{0} \text { is rejected, meaning there is a significant difference } \\
\text { between experimental and control groups }\end{array}$ \\
\hline
\end{tabular}

After the independent sample t-test was conducted, the N-Gain score was employed to analyze the increase of the students' mathematical problem-solving skills in the experimental class and the control class. The $\mathrm{N}$-Gain score analysis was done by using the SPSS program. The following is the result of the N-Gain score analysis.

Table 13.

Descriptive Statistics (N-Gain Score)

\begin{tabular}{|c|c|c|c|c|c|}
\hline & \multicolumn{2}{|c|}{ Experimental } & \multicolumn{2}{|c|}{ Control } \\
\hline & & Statistics & Std. Error & Statistics & Std. Error \\
\hline \multicolumn{2}{|l|}{ Mean } & 44.07 & 2.23 & 31.96 & 1.42 \\
\hline \multirow{2}{*}{$\begin{array}{l}95 \% \text { Confidence } \\
\text { Interval for } \\
\text { Mean }\end{array}$} & Lower Bound & 39.64 & & 29.14 & \\
\hline & Upper Bound & 48.51 & & 34.78 & \\
\hline \multicolumn{2}{|l|}{ Std. Deviation } & 2.17 & & 1.38 & \\
\hline \multicolumn{2}{|l|}{ Minimum Score } & 22.58 & & 15.22 & \\
\hline \multicolumn{2}{|l|}{ Maximum Score } & 100.00 & & 79.17 & \\
\hline
\end{tabular}

Table 14.

The Categorization of N-Gain Score

\begin{tabular}{|c|l|}
\hline Percentage (\%) N-Gain Score & \multicolumn{1}{|c|}{ Category } \\
\hline N-gain $>70$ & High \\
\hline $30 \leq \mathrm{g} \leq 70$ & Moderate \\
\hline N-gain $<30$ & Low \\
\hline
\end{tabular}

(Source: [43])

Table 13 shows that the percentage of $\mathrm{N}$-Gain scores in the experimental class is 44.07, and for the control class is 31.96. Based on the categorization guidelines proposed by [43], which is presented in table 14, the percentage of the N-Gain score in the experimental class is moderate. In conclusion, learning with MBPBL applied to the experimental class is more effective than PBL learning applied to the control class.

\subsection{The students' responses on the implementation of MBPBL}

To reveal the students' responses to the implementation of MBPBL in mathematics learning, the researchers used a questionnaire distributed to 94 students. The questionnaire contains some statements related to students' responses to the learning process. The results are presented as follows: 
Table 15. The Results of Questionnaire Distribution

\begin{tabular}{|c|l|c|c|}
\hline No. & \multicolumn{1}{|c|}{ Statements } & Agree & Disagree \\
\hline 1 & $\begin{array}{l}\text { I like to learn mathematics by using a combination of face-to- } \\
\text { face and online learning compared to face to face learning fully }\end{array}$ & $80 \%$ & $20 \%$ \\
\hline 2 & $\begin{array}{l}\text { Schoology is an exciting media which can be used to facilitate } \\
\text { learning in schools }\end{array}$ & $75 \%$ & $25 \%$ \\
\hline 3 & $\begin{array}{l}\text { MBPBL learning model makes me responsible and discipline to } \\
\text { do the tasks }\end{array}$ & $80 \%$ & $20 \%$ \\
\hline 4 & $\begin{array}{l}\text { MBPBL learning model gives me a new experience in learning } \\
\text { mathematics }\end{array}$ & $65 \%$ & $35 \%$ \\
\hline 5 & $\begin{array}{l}\text { I can save my time to do the tasks through Schoology learning } \\
\text { apps }\end{array}$ & $65 \%$ & $35 \%$ \\
\hline 6 & $\begin{array}{l}\text { MBPBL learning model facilitates me to access learning } \\
\text { materials }\end{array}$ & $85 \%$ & $15 \%$ \\
\hline 7 & $\begin{array}{l}\text { I can improve my understanding of mathematics by learning } \\
\text { through e-books and YouTube videos uploaded in Schoology } \\
\text { learning apps }\end{array}$ & $85 \%$ & $15 \%$ \\
\hline 8 & $\begin{array}{l}\text { I prefer to do the tasks and submit them through Schoology } \\
\text { learning apps rather than face-to-face in class }\end{array}$ & $80 \%$ & $20 \%$ \\
\hline 9 & MBPBL learning model can improve my self-confidence & $85 \%$ & $15 \%$ \\
\hline 10 & MBPBL learning model can reduce my mathematics anxiety & $87 \%$ & $15 \%$ \\
\hline Mean & $78,7 \%$ & $21,3 \%$ \\
\hline
\end{tabular}

The questionnaire above revealed that $78.7 \%$ of respondents agreed with all statement items proposed in the questionnaire. It means that most respondents showed their positive responses to the implementation of MBPBL in mathematics learning. The statement items that got the highest score were number 10 , in which $87 \%$ of respondents agreed that MBPBL can reduce their mathematics anxiety. Then, it goes to statements numbers 6,7 , and $9.85 \%$ of respondents agreed that MBPBL can ease them to access learning materials and agreed that E-materials (such as e-books and YouTube videos) could improve their understanding of mathematics.

Further, MBPBL also can improve their self-confidence. The lowest score goes to statement number 4 and 5 , in which only $65 \%$ of respondents agreed that MBPBL gives them a new experience in learning mathematics, and the use of Schoology Apps can save their time in doing tasks. But, overall, the respondents positively responded to the implementation of MBPBL. In addition, the following findings for the PBL class are the answers of students to PBL learning. 
Table 16. The Results of Questionnaire from PBL Class

\begin{tabular}{|c|l|c|c|}
\hline No. & \multicolumn{1}{|c|}{ Statements } & Agree & Disagree \\
\hline 1 & I like PBL learning & $53 \%$ & $47 \%$ \\
\hline 2 & Whatsapp is an alternative media for learning in schools & $65 \%$ & $35 \%$ \\
\hline 3 & PBL raises my responsibility to do the tasks & $45 \%$ & $55 \%$ \\
\hline 4 & PBL gives me new experience of learning mathematics & $46 \%$ & $54 \%$ \\
\hline 5 & All tasks should be submitted in a printed form & $45 \%$ & $55 \%$ \\
\hline 6 & Books and worksheets make learning easy & $55 \%$ & $45 \%$ \\
\hline 7 & Books and worksheets could improve my understanding in learning & $55 \%$ & $45 \%$ \\
\hline 8 & I prefer to submit my task in a printed form than submitting it via & $47 \%$ & $43 \%$ \\
\hline 9 & WhatsApp/email & $60 \%$ & $40 \%$ \\
\hline 10 & PBL reduces students' mathematics anxiety & $40 \%$ & $60 \%$ \\
\hline Mean & & $51 \%$ & $49 \%$ \\
\hline
\end{tabular}

The top score was in point number 2, 65 percent of the students agreed that WhatsApp media was an alternative media in school education. Then, point number 9 , which is that 65 percent of the students agreed if PBL implementation could gain their students' confidence. On average, students often agree partly to statements 1,6 , and 7 and enjoy studying PBL. Based on the above questionnaire findings, $51 \%$ of respondents agreed with the questionnaire's items based on the indicators that some students replied to PBL lessons positively.

\subsection{Interview results}

To deeply investigate the students' responses to the implementation of MBPBL, the researchers also conducted in-depth interviews with students. The followings are the interview excerpts.

The 1st Informant: This $1^{\text {st }}$ Informant was represented by the student who has high mathematical problem-solving skills.

$\mathrm{R}=$ Researcher, $\mathrm{S}=$ Student

$\boldsymbol{R}:$ What do you think if blended learning (the combination of online and offline)

is implemented in mathematics learning like what we have previously done?

$\boldsymbol{S}$ : Yes, sir. I would be very happy because it can facilitate me in learning and submitting the tasks. It can also motivate me, because the learning is done in various ways. So that it is not monotonous and can reduce our boredom.

Even though the $1^{\text {st }}$ Informant is a student with high mathematical problem-solving skills, he feels bored if it is done traditionally (face-to-face meeting). He states that with online learning, it can make him more motivated in learning mathematics.

$\boldsymbol{R}$ : Do you agree if blended learning is also implemented in other subjects?

$\boldsymbol{S}$ : Yes, of course. I do agree with it. Because blended learning, as we have previously done, is impressive. I become more motivated and disciplined in doing the tasks.

The 1st informant agrees if blended learning is also implemented in other subjects from the interview excerpt above. 
$\boldsymbol{R}:$ Could you understand the learning materials which are presented through blended learning easily?

$\boldsymbol{S}$ : I think, yes. I could learn from e-books, which contain more examples of questions. Further, I also like to learn materials given through YouTube videos. I could re-watch the videos many times until I understand the materials.

The $1^{\text {st }}$ informant also asserts that he could easily understand the learning materials since the e-books and YouTube videos uploaded in the Schoology provide more examples of the materials.

$\boldsymbol{R}$ : Do you feel anxious about online learning?

$S$ : Not at all. On the contrary, if I learn in class through a face-to-face meeting, I often feel nervous and anxious. Online learning provides us much more time to find a solution to our problems, and we do not meet face-to-face with other students so that it can make me enjoy learning.

The $1^{\text {st }}$ informant, who is a student with high mathematical problem-solving skills, also states that he feels more anxious if he learns in a face-to-face meeting.

The 2nd Informant: This 2nd Informant was represented by the student who has moderate mathematical problem-solving skills.

$\boldsymbol{R}$ : Do you like mathematics subject? What about the blended learning method that we have previously done in mathematics class?

$\boldsymbol{S}$ : Yes, of course. I like Mathematics, even though I also sometimes find it difficult to learn and do the tasks. But it is a challenge for me. I also like the blended learning method that had been implemented in mathematics class. I got a new experience, and it makes me more discipline to learn.

From the 2nd informant, it was revealed that he loves mathematics subject even though he sometimes finds difficulties in doing mathematics task. However, he feels challenged by the difficulties he finds. He also asserts that blended learning gives him a new experience and make him more disciplined to learn.

$\boldsymbol{R}$ : How if the blended learning method is implemented in all subjects? Do you agree with it?

$\boldsymbol{S}$ : Sure. I do agree with it. Because I think online learning makes me easy to learn.

Further, he also states that blended learning method is feasible to be implemented in other subjects since it makes him easy to learn.

$\boldsymbol{R}$ :Did you find difficulties in understanding the learning materials delivered by teachers in blended learning?

$\boldsymbol{S}$ : Yes, sometimes. Then I would re-read the materials several times and rewatch the videos until I understand the materials.

From the interview excerpt above, it is found that the $2^{\text {nd }}$ informant always read the materials for several times when he finds the topic is difficult.

$\boldsymbol{R}$ : Why did you never ask questions or give your opinion in the class during face-to-face learning? But, on the contrary, in online learning, you often raise questions and give opinions.

$\boldsymbol{S}$ : If I learn in the class, I feel ashamed with my friends, and I am afraid of making mistakes. 
The interview excerpt above reveals that online class can reduce the students' shyness and fear to raise questions during the learning process as the $2^{\text {nd }}$ informant feels.

The 3rd Informant: This $3^{\text {rd }}$ Informant was represented by the student who has low mathematical problem-solving skills.

\section{$\boldsymbol{R}$ : Do you like mathematics subject?}

$S$ : Honestly, I do not really like it, (smiling.......) Because I often get difficulties in learning mathematics.

The interview excerpt above shows that the $3^{\text {rd }}$ informant does not like mathematics, since he often gets difficulties in mathematics lessons.

$\boldsymbol{P}:$ Then, how about the implementation of blended learning in mathematics class like what we have previously done? Do you like it or not?

$\boldsymbol{S}$ : Yeah, basically, I like blended learning in mathematics class. Online learning leads me to be an independent learner, so that I feel more confident.

The excerpt above shows that the $3^{\text {rd }}$ informant basically likes blended learning method which was implemented in mathematics class because online learning trains him to be an independent learner.

$\boldsymbol{P}$ : One of the topics discussed in blended learning was an arithmetic progression, could you understand it?

$\boldsymbol{S}$ : Yes, I understood the topic of arithmetic progression, but I still get confused with the topic of geometric series, so that I need to re-read the materials several times.

The excerpt above shows that when the 3rd informant does not understand with the learning materials, he reads the materials several times.

$\boldsymbol{P}$ : Do you often feel anxious if you are asked to do the task of mathematics in front of the class?

$\boldsymbol{S}$ : Yes, of course. I am afraid of making a mistake and ashamed of my friends.

The interview excerpt above reveals that the $3^{\text {rd }}$ informant is afraid of making mistake and feels ashamed with their peers when he is asked to do the task in front of the class. It means that face-to-face learning leads more anxiety for students.

\section{Discussion}

\subsection{Is the implementation of MBPBL learning model more effective than conventional PBL?}

Based on the results of this study, it is revealed that there is a significant difference of students' mathematical problem-solving skills between those who were taught by using MBPBL and those who were taught by using PBL. Furthermore, based on the NGain test results, it can be concluded that the MBPBL learning model is more effective than PBL learning to teach mathematical problem-solving skills. This study's results are in accordance with [44], which states that blended-PBL is better than conventional PBL. Another study investigated about PBL also revealed that it has some weaknesses, such as it requires a lot of time allocation compared to traditional learning [11], [12], and it does not provide a significant effect if it is applied in a short time [12]. MBPBL 
is more effective than PBL because the learning steps of MBPBL provide an ample space for students to do problem analysis, understand the material, learn independently, and do assignments. In addition, MBPBL learning steps are also in accordance with the theory of constructivism. Learning occurs through the results of building a knowledgebased experience, where learning aims to make students actively build their knowledge [45].

MBPBL learning model is a combination of Mobile Learning (ML), Blended Learning (BL), and Problem-Based Learning (PBL), all of which have a theoretical foundation. Specifically, blended learning does not have specific learning steps. In this study, mobile learning is an intermediary medium for learning activities, and the learning steps of MBPBL were developed and modified from PBL learning steps. However, the development and modification of MBPBL learning steps are not a problem because blended learning requires a learning model that guarantees its effectiveness in online learning [46]. This development and modification can create a new variation of PBL, which is by the integration of online learning [47]. Blended learning and PBL support each other in the learning process either face to face or online [34]. Dealing with the integration of mobile learning (mobile device in an online learning), several studies reveal its positive impacts on students' achievement [48]-[51]. A study conducted by [48] reveals that mobile devices, such as tablets and computers, will significantly affect students' students' achievement if they are integrated to the learning process frequently.

MBPBL is also effective in developing students' knowledge so that they have good mathematical problem-solving skills. The students who were taught by using MBPBL could learn independently or in group learning because PBL is a holistic learning model in which there is a combination of several approaches and learning methods [52]. In addition, MBPBL learning also gives students experience to learn in analyzing independent or group findings through online discussion and face-to-face, so that it can train students to interact socially because social interaction is also the basis in developing students' cognition.

The focus of the study lies in the integration of mobile phones with blended learning and PBL syntax. This involves the students' abilities for learning and their flexibility in learning and their expertise in using mobile phones in learning. In addition, based on the outcomes of student response questionnaires and interviews, the highest proportion of questionnaire statements can be found in Statement 10, which is about the decrease of students' anxiety during mathematics learning and their nervousness of being laughed by their peers.

The challenge encountered during the implementation of MBPBL learning in this study was related to LMS use. While students had demonstrated and practiced at the beginning of the meeting, they still found some difficulties utilizing the LMS. Consequently, some students made mistakes by misplacing their comments during the discussion. However, the problems were fixed after the students have regularly used the LMS. 


\subsection{How do students respond to MBPBL learning?}

Learning that has been carried out also needs to be assessed or evaluated. One of the assessments is done by giving students questionnaires to assess related to learning that has been carried out. Students' responses to the implementation of learning are needed because learning is a complex process involving teachers and students. Students' responses to learning can influence the effectiveness of learning. Therefore, students' responses to learning mathematics through MBPBL are needed to know to reveal whether or not the model is accepted as an introduction to learning.

The students' attitude towards MBPBL learning in mathematics also shows a positive response. One of the reasons is the integration of mobile devices in an online learning. This is relevant with the study conducted by [53], in which he asserts that the majority of students have positive opinions about mobile devices integrated in online learning. There is no gender and age difference dealing with this opinion. In addition, [54] reveals that pre-service teachers have the most impact on their decision to implement mobile learning, followed similarly by the perceived simple use of the utility of mobile learning in teaching.

Further, when the learning process took place, the students were also engaged in learning by expressing their opinions, asking questions, and group discussions. This can be observed when students learn in an online class and face-to-face classes. The students who were passive during the face-to-face classroom became active during online classes by expressing opinions or asking questions. In addition, some students feel scared, anxious to work in front of the class in a face-to-face class. On the contrary, in the online class, they were happy and active to join the lesson. This is because of the comfortable learning environment in the online class. These findings are in accordance with the study conducted by [38]-[42], in which they state that students who are ashamed tend to participate more actively in online learning than in face-to-face learning. Based on the questionnaire about anxiety, it is revealed that $87 \%$ of the students agreed that MBPBL learning could reduce their anxiety. Students' attitudes towards MBPBL learning are also influenced by the learning atmosphere that makes them feel comfortable both in face-to-face and online learning. The students who can utilize information technology well, their motivation, and self-confidence are increasing [47].

Based on the questionnaire results distributed to students, generally, $78.7 \%$ of the students stated a positive response to MBPBL. This means that the MBPBL learning model is well accepted as a learning model. Therefore, the MBPBL learning model needs more attention in some aspects, such as how students learn and how students respond to the online learning environment because everyone has different learning styles. Students' learning styles in the online environment are also necessary to be identified to develop further online learning.

\section{Conclusion}

This study concludes that MBPBL can be implemented and accepted as a learning model, enhancing the students' mathematical skills and reducing their anxiety. Further, 
the MBPBL learning model is more effective than traditional PBL. Besides, students' response to the implementation of the MBPBL learning model in mathematical learning has been positive. This study's results support the implementation of mobile deviceaided learning, including the use of mobile learning devices. Teachers and students can study everywhere and anywhere on their mobile device. This research study also showed some significant results for integrating mobile devices into blended learning with PBL syntax due to the flexibility in accessing the mobile devices and improved student abilities in the use of mobile devices in learning, as well as training students in doing the tasks with confidence.

This research is, however, limited to mathematical learning in a blended learning context. Therefore, other researchers are suggested to perform future research in the context of purely online learning. The findings of this research will be used to support educators and decision-makers with their practice. Understanding the issues raised in implementing and integrating mobile technology in their schools and instructional methods for greater adoption through effective efforts and interventions. Furthermore, this study recommends that teachers of mathematics or non-Mathematics and subsequent researchers incorporate external factors such as school curriculum, school regulations concerning mobile phone to students, good Internet connectivity, family, etc. to achieve course learning outcomes.

\section{$7 \quad$ Acknowledgement}

This research is partly funded by the Indonesian Endowment Fund for Education (LPDP).

\section{$8 \quad$ References}

[1] C. P. Dwyer, M. J. Hogan, and I. Stewart, "An integrated critical thinking framework for the 21 st century," Think. Ski. Creat., vol. 12, pp. 43-52, 2014, https://doi.org/10. 1016/j.tsc.2013.12.004

[2] R. M. Schmaltz, E. Jansen, and N. Wenckowski, "Redefining critical thinking: Teaching students to think like scientists," Front. Psychol., vol. 8, no. MARET, pp. 2015-2018, 2017, https://doi.org/10.3389/fpsyg.2017.00459

[3] Ijirana and L. Nadjamuddin, "Time series study of problem-solving ability of Tadulako University students using metacognitive skill-based learning model," Int. J. Emerg. Technol. Learn., vol. 14, no. 21, pp. 227-234, 2019, https://doi.org/10.3991/ijet.v14i21.11684

[4] S. Moto, T. Ratanaolarn, S. Tuntiwongwanich, and P. Pimdee, "A Thai junior high school students' 21 st century information literacy, media literacy, and ICT literacy skills factor analysis," Int. J. Emerg. Technol. Learn., vol. 13, no. 9, pp. 87-106, 2018, https://doi.org/10.3991/ijet.v13i09.8355

[5] R. Donnelly, "Harmonizing technology with interaction in blended problem-based learning," Comput. Educ., vol. 54, no. 2, pp. 350-359, 2010, https://doi.org/10. 1016/j.compedu.2009.08.012 
[6] A. Masek and S. Yamin, "The Effect of Problem Based Learning on Critical Thinking Ability: A Theoretical and Empirical Review," Int. Rev. Soc. Sci. Humanit., vol. 2, no. 1, pp. 215-221, 2011, [Online]. Available: www.irssh.com.

[7] R. M. Lopes et al., "Principles of problem-based learning for training and professional practice in ecotoxicology," Sci. Total Environ., vol. 702, p. 134809, 2020, https://doi.org/10.1016/j.scitotenv.2019.134809

[8] E. H. J. Yew and K. Goh, "Problem-Based Learning: An Overview of its Process and Impact on Learning," Heal. Prof. Educ., vol. 2, no. 2, pp. 75-79, 2016, doi: 10.1016/j.hpe. 2016.01.004.

[9] Y. Li and A. H. Schoenfeld, "Problematizing teaching and learning mathematics as 'given' in STEM education,” Int. J. STEM Educ., vol. 6, no. 1, 2019, doi: 10.1186/s40594-0190197-9.

[10] J. A. Blackwell and N. E. Roseth, "Problem-Based Learning in a Woodwind Methods Course: An Action Research Study,” J. Music Teach. Educ., vol. 28, no. 1, pp. 55-69, 2018, https://doi.org/10.1177/1057083718769262

[11] M. A. Ghufron and S. Ermawati, "The strengths and weaknesses of cooperative learning and problem- based learning in EFL writing class: Teachers and students' perspectives," Int. J. Instr., vol. 11, no. 4, pp. 657-672, 2018. https://doi.org/10.12973/iji.2018.11441a

[12] F. Kazemi and M. Ghoraishi, "Comparison of Problem-based Learning Approach and traditional teaching on attitude, misconceptions and mathematics performance of University Students," Soc. Behav. Sci., vol. 46, pp. 3852-3856, 2012, https://doi.org/10. $\underline{1016 / \text { j.sbspro.2012.06.159 }}$

[13] H. Suwono and E. K. Dewi, "Problem-based learning blended with online interaction to improve motivation, scientific communication and higher order thinking skills of high school students," AIP Conf. Proc., vol. 2081, 2019, https://doi.org/10.1063/1.5094001.

[14] A. D., V. Y., and K.-F. S., "How can problem-based learning be realised in blended learning format? Contribution to the HoGe conference 2018 ,Digital learning and teaching/ "Wie kann problembasiertes Lernen im Blended-Learning-Format umgesetzt werden? Beitrag zur HoGe-Tagung 2018 „D,” Int. J. Heal. Prof., vol. 6, no. 1, pp. 90-96, 2019 https://doi.org/10.2478/ijhp-2019-0010

[15] L. T. Car et al., "Digital problem-based learning in health professions: Systematic review and meta-analysis by the digital health education collaboration,” J. Med. Internet Res., vol. 21, no. 2, pp. 1-12, 2019, https://doi.org/10.2196/12945

[16] W. Wahyudi, "The effectiveness of sharing blended project- based learning (SBPBL) model implementation in operating system course," Int. J. Emerg. Technol. Learn., vol. 15, no. 5, pp. 202-211, 2020, https://doi.org/10.3991/ijet.v15i05.11266

[17] N. S. Ismail, J. Harun, M. A. Z. M. Zakaria, and S. M. Salleh, "The effect of Mobile problembased learning application DicScience PBL on students' critical thinking," Think. Ski. Creat., vol. 28, pp. 177-195, 2018, https://doi.org/10.1016/j.tsc.2018.04.002

[18] A. Nurkhin, K. Kardoyo, H. Pramusinto, R. Setiyani, and R. Widhiastuti, “Applying Blended Problem-Based Learning to Accounting Studies in Higher Education; Optimizing the Utilization of Social Media for Learning," Int. J. Emerg. Technol. Learn., vol. 15, no. 08, p. 22, 2020, https://doi.org/10.3991/ijet.v15i08.12201.

[19] I. K. Suartama, P. Setyosari, Sulthoni, and S. Ulfa, "Development of an instructional design model for mobile blended learning in higher education," Int. J. Emerg. Technol. Learn., vol. 14, no. 16, pp. 4-22, 2019, https://doi.org/10.3991/ijet.v14i16.10633

[20] J. Eppard, Z. Hojeij, P. Ozdemir-Ayber, M. Rodjan-Helder, and S. Baroudi, "Using mobile learning tools in higher education: A UAE Case," Int. J. Interact. Mob. Technol., vol. 13, no. 11, pp. 51-69, 2019, https://doi.org/10.3991/ijim.v13i11.10823. 
[21] . Kadek Suartama, P. Setyosari, Sulthoni, and S. Ulfa, "Development of ubiquitous learning environment based on moodle learning management system,” Int. J. Interact. Mob. Technol., vol. 14, no. 4, pp. 182-204, 2020, https://doi.org/10.3991/ijim.v14i14.11775

[22] O. F. Marzouki, M. K. Idrissi, and S. Bennani, "Effects of social constructivist mobile learning environments on knowledge acquisition: A meta-analysis,” Int. J. Interact. Mob. Technol., vol. 11, no. 1, pp. 18-39, 2017, https://doi.org/10.3991/ijim.v11i1.5982

[23] J. Cheon, S. Lee, S. M. Crooks, and J. Song, "An investigation of mobile learning readiness in higher education based on the theory of planned behavior," Comput. Educ., vol. 59, no. 3, pp. 1054-1064, 2012, https://doi.org/10.1016/i.compedu.2012.04.015

[24] B. G. Jayatilleke, G. R. Ranawaka, C. Wijesekera, and M. C. B. Kumarasinha, "Development of mobile application through design-based research," Asian Assoc. Open Univ. J., vol. 13, no. 2, pp. 145-168, 2018, https://doi.org/10.1108/aaouj-02-2018-0013

[25] I. Lestari, A. Maksum, and C. Kustandi, "Mobile learning design models for State University of Jakarta, Indonesia," Int. J. Interact. Mob. Technol., vol. 13, no. 9, pp. 152-171, 2019, https://doi.org/10.3991/ijim.v13i09.10987

[26] W. H. Wu, Y. C. Jim Wu, C. Y. Chen, H. Y. Kao, C. H. Lin, and S. H. Huang, "Review of trends from mobile learning studies: A meta-analysis," Comput. Educ., vol. 59, no. 2, pp. 817-827, 2012, https://doi.org/10.1016/j.compedu.2012.03.016

[27] Y. Dikmenli, "Effect of the blended learning environment and the application of virtual Ülkü Eser Ünaldi," Mevlana Int. J. Educ., vol. 3, no. 2, pp. 43-56, 2013. https://doi.org/10. 13054/mije.13.26.3.2

[28] C. R. Tucker, Blended Learning in Action: A Practical Guide Toward Sustainable Change Audiobook. Corwin: SAGE, 2016.

[29] J. Carman, Blended learning design. Five Key Ingredients, 2005.

[30] C. R. Graham, Blended learning systems: Definition, current trends, and future directions, no. January 2006. 2006.

[31] R. I. Arends, Learning to Teach, Tenth Edit. New York: McGrawHill Education, 2012.

[32] C. E. Hmelo-Silver and H. S. Barrows, "Goals and Strategies of a Problem-based Learning Facilitator,” Interdiscip. J. Probl. Learn., vol. 1, no. 1, pp. 21-39, 2006, https://doi.org/10. 7771/1541-5015.1004

[33] R. Donnelly, "Blended problem-based learning for teacher education: Lessons learnt," J. Learn. Media Technol., vol. 31, no. 2, pp. 93-116, 2006, https://doi.org/10.1080/ 17439880600756621.

[34] O. Delialioglu, "Student Engagement in Blended Learning Environments with LectureBased and Problem-Based Instructional Approaches," Educational Technology \& Society, vol. 15 , no. 3. pp. 310-322, 2012.

[35] H. G. Schmidt, "Problem-based learning: rationale and description," Medical Education, vol. 17, no. 1. pp. 11-16, 1983, https://doi.org/10.1111/j.1365-2923.1983.tb01086.x.

[36] D. F. Wood, "Problem based learning What is problem-based learning?" Bmj, vol. 326, no. February, pp. 328-330, 2003, https://doi.org/10.1136/bmj.326.7384.328

[37] W. C. W. Yu, C. C. Lin, M. H. Ho, and J. Wang, "Technology facilitated PBL pedagogy and its impact on nursing student's academic achievement and critical thinking dispositions,” Turkish Online J. Educ. Technol., vol. 14, no. 1, pp. 97-107, 2015.

[38] S. Al-Salman, "The Role of the Asynchronous Discussion Forum in Online Communication,” J. Instr. Deliv. Syst., vol. 23, no. 2, 2009.

[39] C. J. Bonk, C. R. Graham, J. Cross, and M. G. Moore, "The Handbook of Blended Learning: Global Perspectives, Local Designs,” High. Educ., p. 624, 2012, doi: Book Review. 
[40] C. J. Bonk and K. S. King, Electronic collaborators: Learner-centered technologies for literacy, apprenticeship, and discourse. San Francisco, CA: Pfeiffer Publishing, 1998. https://doi.org/10.4324/9780203053805

[41] S. M. Chong, Models of asynchronous computer conferencing for collaborative learning in large college classes. Mahwah, NJ: Lawrence Erlbaum, 1998.

[42] P. Gerbic, "Chinese Learners and Online Discussions: New Opportunities for Multicultural Classrooms," Res. Pract. Technol. Enhanc. Learn., vol. 1, no. 3, pp. 221-237, 2006, [Online]. Available: https://pdfs.semanticscholar.org/2486/ef3bde5e60305509d845c 117f1bdf7c33cb9.pdf. https://doi.org/10.1142/s1793206806000160

[43] J. Archambault, T. Burch, M. Crofton, and A. Mcclure, "The Effects of Developing Kinematics Concepts Graphically Prior to Introducing Algebraic Problem-Solving Techniques," no. July, 2008.

[44] M. M. Ibrahim, M. Y. H. Arshad, N. A. Shukor, and M. S. Rosli, "Blended Problem Based Learning (BPBL): Opportunities and Challenges to be Implemented in Malaysian Context," in IGCESH 2014, 2014, no. August.

[45] M. Alias and H. H. M. Saleh, "The effect of the blended Problem-Based Learning method on the acquisition of content-specific knowledge in mechanical engineering," World Trans. Eng. Technol. Educ., vol. 6, no. 2, pp. 249-252, 2007.

[46] O. Delialioglu and Z. Yildirim, "Students' perception of effective dimensions of interactive learning in a blended learning environment," Educ. Technol. Soc., vol. 10, no. 2, pp. 133146, 2007, [Online]. Available: http://idt8500.pbworks.com/w/file/fetch/19800537/student perceptions.pdf.

[47] V. Woltering, A. Herrler, K. Spitzer, and C. Spreckelsen, "Blended learning positively affects students' satisfaction and the role of the tutor in the problem-based learning process: Results of a mixed-method evaluation," Adv. Heal. Sci. Educ., vol. 14, no. 5, pp. 725-738, 2009, https://doi.org/10.1007/s10459-009-9154-6

[48] S. Papadakis, M. Kalogiannakis, and N. Zaranis, "The effectiveness of computer and tablet assisted intervention in early childhood students' understanding of numbers. An empirical study conducted in Greece," Educ. Inf. Technol., vol. 23, no. 5, pp. 1849-1871, 2018, https://doi.org/10.1007/s10639-018-9693-7

[49] S. Papadakis, M. Kalogiannakis, and N. Zaranis, "Comparing Tablets and PCs in teaching Mathematics: An attempt to improve Mathematics Competence in Early Childhood Education," Presch. Prim. Educ., vol. 4, no. 2, p. 241, 2016, https://doi.org/10. $\underline{12681 / \text { ppej.8779 }}$

[50] M. Kalogiannakis and S. Papadakis, "The Use of Developmentally Mobile Applications for Preparing Pre-Service Teachers to Promote STEM Activities in Preschool Classrooms," pp. 82-100, 2019, https://doi.org/10.4018/978-1-7998-1486-3.ch005.

[51] M. Kalogiannakis and S. Papadakis, "Combining mobile technologies in environmental education: a Greek case study,” Int. J. Mob. Learn. Organ., vol. 11, no. 2, p. 108, 2017, https://doi.org/10.1504/ijmlo.2017.10005249

[52] S. Şendağ and H. Ferhan Odabaş1, "Effects of an online problem-based learning course on content knowledge acquisition and critical thinking skills," Comput. Educ., vol. 53, no. 1, pp. 132-141, 2009, https://doi.org/10.1016/j.compedu.2009.01.008

[53] [53] S. Papadakis, "Evaluating pre-service teachers' acceptance of mobile devices with regards to their age and gender: A case study in Greece,” Int. J. Mob. Learn. Organ., vol. 12, no. 4, pp. 336-352, 2018, https://doi.org/10.1504/ijmlo.2018.10013372

[54] [54] M. Kalogiannakis and S. Papadakis, "Evaluating pre-service kindergarten teachers' intention to adopt and use tablets into teaching practice for natural sciences," Int. J. Mob. 
Learn. Organ., vol. 13, no. 1, pp. 113-127, 2019, https://doi.org/10.1504/ijmlo.2019. 10016617.

\section{Authors}

Ahmad Kholiqul Amin is a Doctoral Student in Educational Technology Study Program, Universitas Negeri Malang, Indonesia. Email: choliqamin@gmail.com

I Nyoman Sudana Degeng is a Professor at the Postgraduate Program of Educational Technology, Universitas Negeri Malang, Indonesia Email: nyoman. sudana.d.fip@um.ac.id

Punaji Setyosari is a Professor at the Postgraduate Program of Educational Technology, Universitas Negeri Malang, Indonesia. Email: punaji.setyosari.fip@, um.ac.id

Ery Tri Djatmika is a Professor at the Postgraduate Program of Management, Universitas Negeri Malang, Indonesia. Email: ery.tri.fe@um.ac.id

Article submitted 2020-07-31. Resubmitted 2020-10-06. Final acceptance 2020-10-07. Final version published as submitted by the authors. 